\title{
AND NOW WHAT?
}

A Guide to Leadership and Taking

Charge in Your New Role 


\title{
AND NOW WHAT?
}

\section{A Guide to Leadership and Taking Charge in Your New Role}

\author{
BY
}

\section{GUIDO STEIN}

IESE Business School, Madrid, Spain

\section{emerald PUBLISHING}

United Kingdom - North America - Japan - India - Malaysia - China 
Emerald Publishing Limited

Howard House, Wagon Lane, Bingley BD16 1WA, UK

First edition 2018

Copyright (C) 2018 Emerald Publishing Limited

Reprints and permissions service

Contact: permissions@emeraldinsight.com

No part of this book may be reproduced, stored in a retrieval system, transmitted in any form or by any means electronic, mechanical, photocopying, recording or otherwise without either the prior written permission of the publisher or a licence permitting restricted copying issued in the UK by The Copyright Licensing Agency and in the USA by The Copyright Clearance Center. Any opinions expressed in the chapters are those of the authors. Whilst Emerald makes every effort to ensure the quality and accuracy of its content, Emerald makes no representation implied or otherwise, as to the chapters' suitability and application and disclaims any warranties, express or implied, to their use.

British Library Cataloguing in Publication Data

A catalogue record for this book is available from the British Library

ISBN: 978-1-78743-526-1 (Print)

ISBN: 978-1-78743-525-4 (Online)

ISBN: 978-1-78743-540-7 (Epub)

\section{ISOQAR certified}

Management System,

awarded to Emerald

for adherence to

Environmental

$\begin{array}{ll}\text { ISOQAR } & \text { standard } \\ \text { ISO 14001:2004 }\end{array}$ 
To the participants in my programs, from whom I learn every day. 


\section{CONTENTS}

Acknowledgments

Preface $\quad$ xi

1. Introduction: A Personal Adventure 1

\section{PART 1}

KEYS FOR TAKING CHARGE

2. A New Identity: Developing a Different Perspective 15

3. Taking Charge and Change: Personal Performance 31

4. How to Prepare Taking Charge Effectively 43

5. Company Culture and Taking Charge:

The Role of the Setting 65

6. People Management: The Core of Taking Charge 89

7. Landing into a Merger: Putting People First 121

\section{PART 2}

\section{FROM THEORY TO REALITY}

8. Everyday Factors

9. First Managerial Stages: Yolanda Cruz in Health and Beauty 
10. Changes and Promotions: Reiner Meinhold in Kölner Bank

11. The Second Take Off: People versus Results. West Line 209

12. Entering Top Management: Sybila Börjesson in Catek 237

13. Staying in the Job: General Manager of Contents in VivaVisión

14. A Career in International Landings: Andrés Cardó in Prisa Group

15. The Chairman's Challenges: Eric Laborde in Pernod Ricard

Epilogue: Leading Oneself

Bibliography

Index 


\section{ACKNOWLEDGMENTS}

The chapter of thanks is limitless, for this reason I will make a poor but viable synthesis. I would like to once again thank my wife Luisa, with her Galician instinct and her clinical eye, for her contribution in successfully bringing out the title. My Jaime, Alicia, Luisa, José-Otto, Guido, and Juan have contributed efficaciously to delay the publication, something that I will never be able to thank them enough for.

My colleagues, Professors José Ramón Pin and Juan Roure, introduced me to this topic, and the IESE allowed me to develop it most generously: I extend my thanks to them, and I would also like to Mireia Acosta, Leopoldo Boado, Enrique Cano, Andrés Cardó, Enrique Cebrecos, Ángel Cervantes, Melanie De La Vega, Jaime de Jaráiz, Eric Laborde, Juan Manuel Negro, Teresa Wesolowski, and an et cétera which hides my bad memory.

Finally, although only in a temporal sense, my acknowledgments to Miguel Martín, Marta Cuadrado, and Alberto Ortíz, who in their work as research assistants have made an extraordinary and detailed contribution; the book is also theirs. Also my warmest thanks to the editor Pete Baker for making the dream possible in Emerald Group. 


\section{PREFACE}

Life shows us that the most important decision is the next one, not the last one, and that decision is always made now.

We live looking forward, but we understand things looking back; from there we can learn from our errors and successes, and for that same reason, also improve. And Now What? deals precisely with learning in order to improve as managers of others, beginning with ourselves.

The book arose from my classes in IESE Business School and from my advisory activity with managers and businesspeople facing the challenges occurring in their professional careers in times of change, which are, surprisingly, constant. On the base of facing reality and studying how other colleagues had analyzed similar situations, I became encouraged to throw in my contribution. Each page was originally written to be discussed in class, which allowed me to learn more, given that I have the gratifying privilege of being taught by my students. Better equipped after that exchange of ideas, I have faced day to day with renewed energy to apply what was discussed; to return later to class and carry on outlining the theory, which is nothing more than a view of reality; and thus repeatedly, in a loop which is as exciting as it is enriching. The readers have in their hands what I have seen regarding the landing (taking charge) of a manager in a new post.

The book begins with an introduction, which everyone knows is the last to be written, that offers a panoramic perspective of what a landing entails in terms of personal self-leadership and managing people and uncertainty challenges and then is structured into two parts. Part 1 intends to be a systematic review of the 
several phases of a taking charge process from preparation to implementation in the most difficult environment of a merger or acquisition.

Chapter 2 addresses the traits which characterize what the manager arriving in a new post has to do, and the efforts to adapt that are demanded. We will take the reader from creating expectations with the initial messages of the new manager and the role played by trust and credibility in the first steps.

Chapter 3 discusses the impacts of the change that a landing entails and how to manage them. The reader will understand how prioritizing improves time management and the quality of decision-making, and how anticipation in a changing environment will avoid mistakes in communication and action implementation.

Chapter 4 proposes an integrating scheme of the factors which shape the landing. After having pondered them, the reader may develop a mental plan and a real approach, where renovating the skills facing the challenges will make the difference.

Chapter 5 notes the influence that the company culture, in both the formal and the informal or spontaneous versions exert on the recent landing and how to handle it. The reader will acquire a set of tools to assess the current culture and design the path to the new one.

Chapter 6 describes some key points on how to manage the protagonists of every landing: people. The reader will become acquainted with the keys of selection, hiring, training, development, evaluation and compensation policies, vital for a safe landing.

Chapter 7 addresses the situation of landing in a merger or an acquisition, once again emphasizing the hardest part of leadership which is often delayed or neglected. It offers an agenda to deal successfully with people uncertainty and traumas, making communication an ingredient of the solution and not of the problem.

Part 2 offers a range of real cases, although some with fictitious names in order to protect the identities of the protagonists, with a 
brief analysis, arranged in a chronological order as they acquire greater responsibilities. This provides reality and facts. The reader will take a trip from the first stages of a professional life as leader to the highest responsibilities of the chairman's role, experiencing changes, promotions, exits, internationalizations, and takeoffs.

One has the right to a personal opinion; that is legitimate, as is respectable the way in which it has been formed, but one doesn't have the right to personal facts; if not, agreements would be impossible or nonviable because of their instability, and learning a chimera. The cases allow the reader to bring into play what has been dealt with in Part 1, go from theory to reality, so that one's own judgment is formed. This is the author's final intention. 